\title{
Mortality and morbidity among people living close to incinerators: a cohort study based on dispersion modeling for exposure assessment
}

\author{
Andrea Ranzi ${ }^{1 \dagger}$, Valeria Fano ${ }^{2 \dagger}$, Laura Erspamer ${ }^{1}$, Paolo Lauriola', Carlo A Perucci ${ }^{2}$ and Francesco Forastiere ${ }^{2^{*}}$
}

\begin{abstract}
Background: Several studies have been conducted on the possible health effects for people living close to incinerators and well-conducted reviews are available. Nevertheless, several uncertainties limit the overall interpretation of the findings. We evaluated the health effects of emissions from two incinerators in a pilot cohort study.

Methods: The study area was defined as the $3.5 \mathrm{~km}$ radius around two incinerators located near Forli (Italy). People who were residents in 1/1/1990, or subsequently became residents up to $31 / 12 / 2003$, were enrolled in a longitudinal study (31,347 individuals). All the addresses were geocoded. Follow-up continued until 31/12/2003 by linking the mortality register, cancer registry and hospital admissions databases. Atmospheric Dispersion Model System (ADMS) software was used for exposure assessment; modelled concentration maps of heavy metals (annual average) were considered the indicators of exposure to atmospheric pollution from the incinerators, while concentration maps of nitrogen dioxide $\left(\mathrm{NO}_{2}\right)$ were considered for exposure to other pollution sources. Age and area-based socioeconomic status adjusted rate ratios and 95\% Confidence Intervals were estimated with Poisson regression, using the lowest exposure category to heavy metals as reference.

Results: The mortality and morbidity experience of the whole cohort did not differ from the regional population. In the internal analysis, no association between pollution exposure from the incinerators and all-cause and causespecific mortality outcomes was observed in men, with the exception of colon cancer. Exposure to the incinerators was associated with cancer mortality among women, in particular for all cancer sites (RR for the highest exposure level $=1.47,95 \% \mathrm{Cl}: 1.09,1.99$ ), stomach, colon, liver and breast cancer. No clear trend was detected for cancer incidence. No association was found for hospitalizations related to major diseases. $\mathrm{NO}_{2}$ levels, as a proxy from other pollution sources (traffic in particular), did not exert an important confounding role.

Conclusions: No increased risk of mortality and morbidity was found in the entire area. The internal analysis of the cohort based on dispersion modeling found excesses of mortality for some cancer types in the highest exposure categories, especially in women. The interpretation of the findings is limited given the pilot nature of the study.
\end{abstract}

\section{Background}

Several studies on the possible health effects related to residing close to incinerators have been published and well-conducted reviews are available [1-3]. Results from ecological studies have suggested associations with some reproductive outcomes (infant deaths and congenital malformations [4]; birth defects [5]; congenital anomalies and stillbirths [6]; gestational age [7]) and with

\footnotetext{
* Correspondence: forastiere@asplazio.it

† Contributed equally

${ }^{2}$ Department of Epidemiology - Lazio Regional Health Service, Rome, Italy

Full list of author information is available at the end of the article
}

cancer (all cancer, larynx, lungs, esophagus, stomach, intestine, liver, kidneys, bladder and breast) [8,9]. However, there are several weaknesses of these results due to design issues such as lack of exposure information and use of surrogate measures such as distance from the source, lack of control for potential confounders. Therefore several uncertainties limit the overall interpretation of the findings. More detailed studies on incinerators in France and in Italy suggest an increased risk for nonHodgkin's lymphoma [10-12], soft-tissue sarcoma $[13,14]$ and urinary tract birth defects [15].

\section{Biomed Central}


These contradictory results do not permit resolution of the issue, and concerns of people living in areas near incinerators require more in-depth studies [1-3]. Recent investigations have used dispersion models to assess population exposure [11,12], an approach that provides a better exposure assessment than studies based on distance from the source. However, such studies have used health data at the aggregate level with numerator and denominator information coming from different sources and with limited possibility of adjusting for confounding related to socioeconomic status. The present work proposes an approach in which exposure assessment is based on geographical characterization by means of dispersion models, outcome information is collected within an individualbased retrospective longitudinal study, and an area-based socioeconomic status index is considered in the analysis.

The aim of the study was to evaluate the health effects of emissions from two incineration plants in the nearby resident population (Emilia-Romagna, Italy), while considering the effects of other environmental stressors and socioeconomic status. Given the limited size of the study and the consequent low statistical power, we considered this approach as a pilot study before addressing the issue in the future using the same methodology to evaluate the effects of other seven plants located in the Emilia-Romagna region.

\section{Methods}

\section{Characteristics of the plants}

The municipality of Forlì $(107,827$ inhabitants in 2001) is located in the Po valley (Emilia Romagna region, Northern Italy). Two incinerators are located about $3 \mathrm{~km}$ from the town, about $200 \mathrm{~m}$ from each other (Figure 1):

- an incinerator of municipal solid waste (MSW) that began operating in 1976 with two lines (capacity of $35,000 \mathrm{Nm}^{3} / \mathrm{h}$, stack height $60 \mathrm{~m}$.); a first renewal was completed in 1993 (capacity of 58,000 $\mathrm{Nm}^{3} / \mathrm{h}$ ), and, finally, in 2000 a plant renovation brought the total capacity to $60,000 \mathrm{Nm}^{3} / \mathrm{h}$ (stack diameter $2.2 \mathrm{~m}$, exit velocity $6.5 \mathrm{~m} / \mathrm{s}$ ).

- an incinerator for hospital waste (HW) that began activity in 1991 (stack height 39 m., capacity 7,500 $\left.\mathrm{Nm}^{3} / \mathrm{h}\right)$, the authorized capacity was extended to 9 , $500 \mathrm{Nm}^{3} / \mathrm{h}$ in 1997 and to $12,500 \mathrm{Nm}^{3} / \mathrm{h}$ in 1999 . In 2003, a new plant was activated with a total capacity of $21,500 \mathrm{Nm}^{3} / \mathrm{h}$ and a stack of $49 \mathrm{~m}$ of height (stack diameter $0.95 \mathrm{~m}$, exit velocity $10 \mathrm{~m} / \mathrm{s}$ ).

The position and the structure of the two plants has remained substantially the same over time (the only substantial change was the height of the HW chimney). Historical emissions data based on routine checks are only available back to 1994 and indicate that between 1994 and

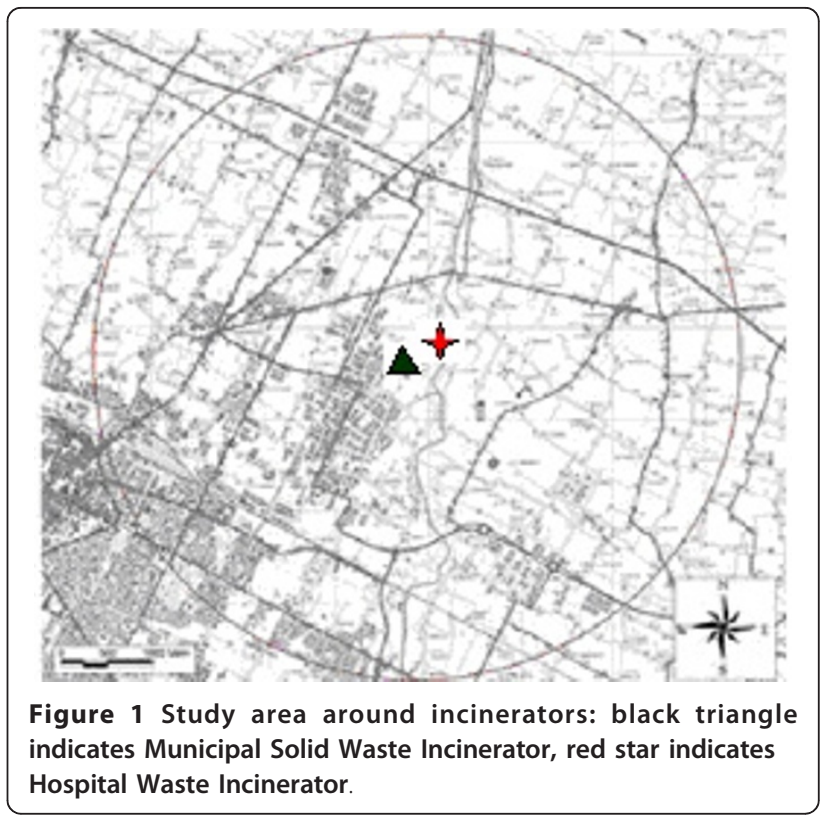

1996 high values of dioxins were emitted by the MSW plant [16]. The emissions of main pollutants significantly decreased in recent years, as shown in the Table 1 for the MSW plant.

\section{The study area}

The study area was defined as the $3.5 \mathrm{~km}$ radius circle around the two incinerators (the central point was the middle distance between the two) (Figure 1), on the basis of the previous literature $[8,10]$ and the results of the dispersion model (see below). Most of the area included in the study is used for agriculture; the remaining territory and the borders of the urban area are occupied by three small industrial areas and by an urban district of the city of Forlì. Besides the incineration plants, the other main sources of air pollution are traffic (from urban area and two major roadways), and domestic heating during winter.

\section{ADMS simulations}

To define the exposure conditions in the area, we used the results of an environmental study conducted during

Table 1 MSW plant emissions of Total Suspended Particulates (TSP), Mercury (Hg), Cadmium (Cd), and Dioxins (PCDD+PCDF) in 1994/1996 and in 2008

\begin{tabular}{ccccc}
\hline Period & Unit of measurement & $\mathbf{1 9 9 4 - 1 9 9 6}$ & $\mathbf{2 0 0 8}$ & ratio \\
\hline $\mathrm{TSP}$ & $\mathrm{mg} / \mathrm{Nm}^{3}$ & 4.6 & 0.991 & 0.214 \\
$\mathrm{Hg}$ & $\mu \mathrm{g} / \mathrm{Nm}^{3}$ & 23.2 & 0.476 & 0.020 \\
$\mathrm{Cd}^{*}$ & $\mu \mathrm{g} / \mathrm{Nm}^{3}$ & 21.0 & 0.422 & 0.020 \\
$\mathrm{PCDD}+\mathrm{PCDF} F^{*}$ & $\mathrm{ng} / \mathrm{Nm}^{3}$ & 128.7 & 0.018 & 0.0001 \\
\hline
\end{tabular}

${ }^{*}$ Cd only in 1994-96, Cd+Tl in 2008.

**Total dioxins in 1994-96, TEQ dioxins in 2008. 
the period 1997-2000 [17]. On the basis of emission inventories of all the environmental factors currently present in the study area (road traffic, industrial plants, incinerators and heating), the quasi-Gaussian model Atmospheric Dispersion Modeling System (ADMS) Urban 2.2 [18] was used to simulate the impact of the different emission sources. Estimated annual average concentration maps of several pollutants $\left(\mathrm{NO}_{2}, \mathrm{SOx}\right.$, $\mathrm{COV}, \mathrm{CO}, \mathrm{TSP}, \mathrm{C} 6 \mathrm{H} 6, \mathrm{HCl}$ and heavy metals) were produced. Heavy metals were the entire set included in the current legislation for industrial emissions, i.e.: lead, cadmium, mercury, antimony, arsenic, chromium, cobalt, copper, manganese, nickel, vanadium, tin.

Based on these preliminary models, points of maximum and minimum fallout for pollutants emitted from the incinerators were identified. Moreover, a point of maximum fallout for all sources was identified. Several monitoring campaigns were conducted to measure concentrations at the points of maximum and minimum fallout using passive samplers, bulk passive sampler, Wet\&Dry and soil depositions for measurements and determinations of SOx, $\mathrm{NO}_{2}, \mathrm{CO}, \mathrm{TSP}, \mathrm{BTX}, \mathrm{HCl}$, PCDD/F, PAH, PCB and heavy metals. The best results were found for heavy metals since the highest concentrations were found at the point of maximum fallout from incinerators, the lowest concentrations at the point of minimum fallout, while intermediate values were found at the point of maximum fallout for all sources. The same was not true for the other measured pollutant, including dioxins and hydrochloric acid, with no clear relation between the estimated points of minimum and maximum fallout and the actual concentrations.

As a result, we decided to consider heavy metals as the tracer of pollution from incinerators. We ran the ADMS model using the characteristics of the plants, and authorized limits of emissions for heavy metals as for early 1990s. We are aware that the regulations changed during the following ten years but we preferred to represent exposure as it was in the past. The current situation was also simulated using more recent authorized limit of emissions (year 2005), in order to verify the exposure gradients in the different scenarios.

Nitrogen dioxide $\left(\mathrm{NO}_{2}\right)$ was identified as the best tracer of air pollution from all other sources. However, it was not possible to reconstruct the emission scenario for the other environmental pressure factors in the past, so current emission factors were used based on the available emission inventories and the authorized values for emissions.

The ADMS requires hourly information about wind speed/direction, total cloud amount, and air temperature to calculate atmospheric boundary layer parameters. Hourly surface meteorological data from the Meteorological Service of the Regional Agency for Environmental
Prevention (ARPA Emilia Romagna) station network were acquired to build the meteorological file for the years of simulation.

Model outputs were mapped using ArcView GIS 8.2 [19] on an "intelligent" grid based on $100 \times 100$ fixed nodes (rectangle of $7518 \times 7618 \mathrm{~m}$.) of the study area to develop concentration grids for each tracer pollutant. We constructed map layers by means of surface interpolations (simple kriging) and obtained the concentration maps for heavy metals and $\mathrm{NO}_{2}$.

\section{Enrolment of the cohort and follow-up procedures}

The General Registry Office of Forlì was the data source for the enrolment of the cohort. Subjects who resided in the study area on $1 / 1 / 1990$, or who subsequently became residents until 31/12/2003, were enrolled in a retrospective longitudinal study. For those subjects who entered in the area after $1 / 1 / 1990$, a minimum of five years of residence was required before starting the follow- up. The follow-up was carried out through record linkage with the regional mortality database (from 1990 to 2003) which includes all deaths of the resident population from anywhere in the country. The Cancer Registry database (from 1990 to 2003) and the Hospital Admissions database (from 1999 to 2003), provided by the Romagna Cancer Registry and the Regional Health Information System, were also used. Hospital admissions for specific causes were considered relevant for the study to evaluate cardiovascular and respiratory morbidity; the first admission for each subject and each cause was included in the analysis. Subjects were considered at risk for the various outcomes (mortality, cancer incidence, or hospitalization) until they died, moved outside the region, or until the last day of the follow-up (31/12/2003). The General Registry Office traced the geographical coordinates of all residences after 1990 but residential histories before 1990 were not available. The relevant residence of each subject was his or her home in 1990 or the first residence for later arrivals.

\section{Exposure indicators}

We used the geo-coded addresses to define residential exposures. Each subject in the cohort was assigned a value of heavy metals and $\mathrm{NO}_{2}$ corresponding to the estimated map values at the residence from the ADMS dispersion model. Quartiles of the distribution of the total population were calculated for heavy metals and $\mathrm{NO}_{2}$. The final categorization, however, was finely adjusted to consider the natural cut-off points.

Based on census data from 2001 for the area of Forlì, an area-based indicator (census block) of socio-economic status (SES) was defined. A total of 1,116 census areas with at least 20 people for the town of Forlì were considered. Four census variables were chosen to represent 
different levels of social advantage: education, employment, housing conditions, and family composition. A factorial analysis was conducted, to define a composite indicator of socioeconomic position, combining algebraic indicators and using the weight factor scores. The final categories of the SES indicator (from low to high social class) were based on the population distribution (quintiles) of the composite index.

\section{Data analyses}

For all health outcomes considered, a preliminary analysis was carried out in order to compare mortality and morbidity of the entire cohort with an external reference area. SMR (Standardized Mortality Ratio) and SIR (Standardize Incidence Ratio) were calculated to compare mortality and cancer incidence of the cohort with the regional population or with the local health district population for hospital admissions.

In the integrated database of the cohort, for each individual we had demographic information, SES level, exposure levels at the residence for heavy metals and $\mathrm{NO}_{2}$, date of entry, date of exit and several outcomes (mortality, incidence, and hospitalization). Person-years at risk were calculated by calendar period, gender and age. Age and socioeconomic status adjusted rate ratios (RR) and 95\% Confidence Intervals (95\% CI) of the association with heavy metal exposure were estimated with Poisson regression separately for males and females and for all the health outcomes considered, using the lowest exposure category as the reference. The choice of the relevant outcomes was based on the literature review. Analyses for soft tissue sarcoma were performed also by combining the results for men and women. To evaluate the possibility of confounding from traffic-related air pollution, we ran an additional analysis using $\mathrm{NO}_{2}$ levels as an adjustment factor. We considered $a$ priori that the associations to be noted were those with an increasing trend in the adjusted rate ratios across the exposure categories and/or a statistically significant rate ratio in the third or fourth quartiles when compared with the first one.

The statistical package STATA was used for all analyses [20].

\section{Results}

The estimated annual average heavy metals concentration throughout the study area was $1.08 \mathrm{ng} / \mathrm{m}^{3}$ (standard deviation, $\mathrm{SD}=1.03)$ in 1990 and $0.46 \mathrm{ng} / \mathrm{m}^{3}$ $(\mathrm{SD}=0.45)$ in 2005 . The annual average $\mathrm{NO}_{2}$ value in 2005 was $37.46 \mu \mathrm{g} / \mathrm{m}^{3}$ (SD = 6.56). The concentration maps for heavy metals estimated for 1990 and for 2005 are illustrated in Figure 2a and Figure 2b, respectively. The relative population distributions are rather similar in the two exposure scenarios, although the absolute values are different. Figure $2 \mathrm{c}$ illustrates the $\mathrm{NO}_{2}$ concentration map in 2005 indicating no spatial correlation with predicted heavy metals concentrations.

A total of 31,347 individuals were enrolled in the cohort (51.7\% females). Their main characteristics in relation to the four categories of residential exposure to heavy metals are described in Table 2. The gender and age distribution was rather similar over the four exposure categories (although people in the second category tended to be younger than in other categories) whereas socioeconomic status and $\mathrm{NO}_{2}$ exposure were different. People in the highest heavy metal exposure categories tended to have a lower socioeconomic status than those in the lowest categories (low social class: $8.6 \%$ in the lowest heavy metal category versus $20.6 \%$ in the highest) while $\mathrm{NO}_{2}$ levels were highest in the low heavy metal group. As indicated at the bottom of the table, most of the cohort members (93.1\%) remained in the initial heavy metals category throughout the follow-up. A total of 3,407 deaths (1,753 males, 1,654 females) were observed during the study period with a total of 354,702 years of observation.

The analyses of the overall cohort mortality compared with regional rates indicated an all causes standardized mortality ratio, SMR, lower than expected both in men $(\mathrm{SMR}=0.91,95 \% \mathrm{CI}=0.87-0.96)$ and women $(\mathrm{SMR}=$ $0.92,95 \% \mathrm{CI}=0.87-0.96)$; cancer mortality and hospital admissions did not differ from the reference population, although some excesses in mortality were found for pleural cancer in men $(\mathrm{SMR}=3.64,95 \% \mathrm{CI}=1.66-6.91)$ and bladder cancer in women $(\mathrm{SMR}=1.76,95 \% \mathrm{CI}=$ 1.01-2.86). Results for cancer incidence confirmed the pleural cancer excess in men (standardized incidence ratio, $\mathrm{SIR}=2.14,95 \% \mathrm{CI}=1.03-3.94)$, while an excess of breast cancer in women $(\mathrm{SIR}=1.15,95 \% \mathrm{CI}=1.03-1.27)$ was found.

Table 3 reports the results of the internal analyses of the association between heavy metal exposure and cause-specific mortality. No clear trend of all-cause or cause-specific mortality in relation to estimated heavy metals concentrations was observed in males. It should be noted, however, that an increase in mortality from all causes and from respiratory diseases was found in the second exposure category when compared with the reference. Also among women, no clear trend in allcause and cause-specific mortality was observed. However, higher mortality was observed in all three exposure categories for all causes and for cardiovascular diseases when compared with the reference category.

The results for hospital admissions for cardiovascular and respiratory causes (Table 4 ) in both sexes confirm the non-positive results observed for mortality. An increase in chronic heart failure only in men was found in the second category of exposure without a noteworthy trend. 


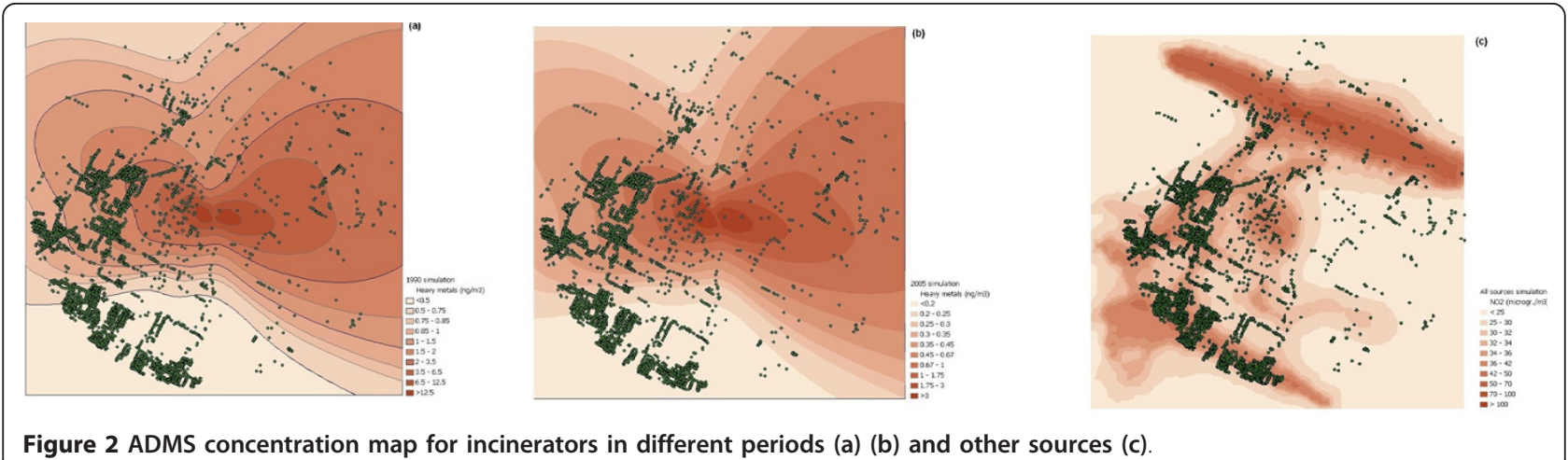

Figure 2 ADMS concentration map for incinerators in different periods (a) (b) and other sources (c).

Table 2 Characteristics of the cohort of residents in the area of Coriano (Italy) during the period 1990-2003 by estimated air concentration of healvy metals

\begin{tabular}{|c|c|c|c|c|c|c|c|c|c|c|}
\hline & \multicolumn{8}{|c|}{ Heavy metals air concentration } & & \\
\hline & \multirow{2}{*}{\multicolumn{2}{|c|}{$\begin{array}{c}\mathrm{I} \\
<0.5 \mathrm{ng} / \mathrm{m} 3\end{array}$}} & \multirow{2}{*}{\multicolumn{2}{|c|}{$\begin{array}{c}\text { II } \\
0.5-1 \mathrm{ng} / \mathrm{m} 3\end{array}$}} & \multirow{2}{*}{\multicolumn{2}{|c|}{$\begin{array}{c}\text { III } \\
1-2 \mathrm{ng} / \mathrm{m} 3\end{array}$}} & \multirow{2}{*}{\multicolumn{2}{|c|}{$\begin{array}{c}\text { IV } \\
>2 \mathrm{ng} / \mathrm{m} 3\end{array}$}} & \multirow{2}{*}{\multicolumn{2}{|c|}{ Total }} \\
\hline & & & & & & & & & & \\
\hline & $\mathrm{n}$ & $\%$ & n & $\%$ & $\mathrm{n}$ & $\%$ & n & $\%$ & n & $\%$ \\
\hline Total & 10391 & 33.1 & 7961 & 25.4 & 9400 & 30.0 & 3595 & 11.5 & 31347 & 100.0 \\
\hline \multicolumn{11}{|l|}{ gender } \\
\hline male & 4966 & 47.8 & 3775 & 47.4 & 4602 & 49.0 & 1811 & 50.4 & 15154 & 48.3 \\
\hline female & 5425 & 52.2 & 4186 & 52.6 & 4798 & 51.0 & 1784 & 49.6 & 16193 & 51.7 \\
\hline \multicolumn{11}{|l|}{ age (years) } \\
\hline $0-44$ & 5051 & 48.6 & 4178 & 52.5 & 4414 & 47.0 & 1720 & 47.8 & 15363 & 49.0 \\
\hline $45-59$ & 2457 & 23.6 & 1808 & 22.7 & 2347 & 25.0 & 894 & 24.9 & 7506 & 23.9 \\
\hline $60-74$ & 1780 & 17.1 & 1266 & 15.9 & 1548 & 16.5 & 614 & 17.1 & 5208 & 16.6 \\
\hline $75+$ & 1103 & 10.6 & 709 & 8.9 & 1091 & 11.6 & 367 & 10.2 & 3270 & 10.4 \\
\hline \multicolumn{11}{|l|}{ Socioeconomic status } \\
\hline low & 871 & 8.6 & 405 & 5.3 & 1294 & 14.7 & 656 & 20.6 & 3226 & 10.8 \\
\hline medium low & 2289 & 22.5 & 659 & 8.6 & 3844 & 43.7 & 1088 & 34.1 & 7880 & 26.4 \\
\hline medium & 2893 & 28.4 & 1633 & 21.3 & 2650 & 30.1 & 942 & 29.6 & 8118 & 27.2 \\
\hline medium high & 3311 & 32.6 & 2515 & 32.8 & 932 & 10.6 & 500 & 15.7 & 7258 & 24.3 \\
\hline high & 805 & 7.9 & 2447 & 31.9 & 74 & 0.8 & 0 & 0.0 & 3326 & 11.2 \\
\hline missing & 222 & 2.1 & 302 & 3.8 & 606 & 6.4 & 409 & 11.4 & 1539 & 4.9 \\
\hline \multicolumn{11}{|l|}{$\mathrm{NO}_{2}$ concentration } \\
\hline$<30 \mu \mathrm{g} / \mathrm{m}^{3}$ & 2624 & 25.3 & 1404 & 17.6 & 2851 & 30.3 & 956 & 26.6 & 7835 & 25.0 \\
\hline $31-35 \mu \mathrm{g} / \mathrm{m}^{3}$ & 2369 & 22.8 & 4188 & 52.6 & 3554 & 37.8 & 1478 & 41.1 & 11589 & 37.0 \\
\hline $36-40 \mu \mathrm{g} / \mathrm{m}^{3}$ & 2012 & 19.4 & 2012 & 25.3 & 1896 & 20.2 & 932 & 25.9 & 6852 & 21.9 \\
\hline$>40 \mu \mathrm{g} / \mathrm{m}^{3}$ & 3386 & 32.6 & 357 & 4.5 & 1099 & 11.7 & 215 & 6.0 & 5057 & 16.1 \\
\hline \multicolumn{11}{|l|}{ Change of exposure during follow-up } \\
\hline never & 9744 & 93.8 & 7175 & 90.1 & 8737 & 92.9 & 3252 & 90.5 & 29185 & 93.1 \\
\hline one o more changes & 647 & 6.2 & 786 & 9.9 & 663 & 7.1 & 343 & 9.5 & 2462 & 7.9 \\
\hline Person years & 120568 & & 90980 & & 103015 & & 40139 & & 354702 & \\
\hline
\end{tabular}

Totals for different variables may vary because of missing values. 
Table 3 Associations between heavy metals concentration and mortality in the cohort of residents in the area of Coriano (Italy) by cause of death (ICD-9) and gender

\begin{tabular}{|c|c|c|c|c|c|c|c|c|c|}
\hline \multirow[b]{2}{*}{ Cause (ICD-9) } & \multirow[t]{2}{*}{ Heavy metals $^{\dagger}$} & \multicolumn{4}{|c|}{ Men } & \multicolumn{4}{|c|}{ Women } \\
\hline & & obs $^{\S}$ & $\mathrm{RR}^{\S \S}$ & \multicolumn{2}{|c|}{$95 \% \mathrm{Cl}$} & obs $^{\S}$ & $\mathrm{RR}^{\S \S}$ & \multicolumn{2}{|c|}{$95 \% \mathrm{Cl}$} \\
\hline \multirow[t]{4}{*}{ All causes (0-999) } & I & 549 & 1.00 & - & - & 495 & 1.00 & - & - \\
\hline & II & 503 & $1.14^{*}$ & 1.00 & 1.29 & 514 & $1.19^{*}$ & 1.09 & 1.30 \\
\hline & III & 502 & 1.05 & 0.92 & 1.19 & 460 & $1.09^{*}$ & 1.00 & 1.20 \\
\hline & IV & 199 & 1.01 & 0.86 & 1.20 & 185 & $1.12^{*}$ & 1.00 & 1.27 \\
\hline \multirow[t]{4}{*}{ Cardiovascular diseases (390-459) } & $\mathbf{I}$ & 215 & 1.00 & - & - & 195 & 1.00 & - & - \\
\hline & II & 183 & 1.01 & 0.82 & 1.24 & 235 & $1.39^{*}$ & 1.14 & 1.70 \\
\hline & III & 191 & 1.06 & 0.86 & 1.29 & 194 & 1.21 & 0.98 & 1.49 \\
\hline & IV & 72 & 0.98 & 0.75 & 1.29 & 78 & 1.32 & 1.00 & 1.72 \\
\hline \multirow[t]{4}{*}{ Ischaemic heart diseases (410-414) } & I & 101 & 1.00 & - & - & 73 & 1.00 & - & - \\
\hline & II & 77 & 0.83 & 0.61 & 1.14 & 81 & 1.26 & 0.90 & 1.76 \\
\hline & III & 77 & 0.93 & 0.68 & 1.26 & 75 & 1.24 & 0.88 & 1.73 \\
\hline & IV & 27 & 0.79 & 0.51 & 1.22 & 25 & 1.14 & 0.72 & 1.82 \\
\hline \multirow[t]{4}{*}{ Respiratory diseases (460-519) } & $\mathbf{I}$ & 19 & 1.00 & - & - & 26 & 1.00 & - & - \\
\hline & II & 31 & $2.07^{*}$ & 1.14 & 3.77 & 26 & 1.18 & 0.67 & 2.11 \\
\hline & III & 23 & 1.35 & 0.72 & 2.53 & 19 & 0.92 & 0.50 & 1.70 \\
\hline & IV & 7 & 1.01 & 0.42 & 2.45 & 4 & 0.53 & 0.18 & 1.56 \\
\hline Chronic pulmonary - & I & 15 & 1.00 & - & - & 13 & 1.00 & - & - \\
\hline \multirow[t]{3}{*}{ diseases (490496) } & II & 16 & 1.40 & 0.67 & 2.95 & 12 & 1.09 & 0.47 & 2.52 \\
\hline & III & 14 & 0.99 & 0.47 & 2.12 & 10 & 0.93 & 0.40 & 2.19 \\
\hline & IV & 3 & 0.53 & 0.15 & 1.86 & 1 & 0.27 & 0.03 & 2.06 \\
\hline
\end{tabular}

*p-value < 0.05; † Categories of heavy metals: I (reference) $<0.5$ ng/m3; II 0.5-1 ng/m3; III 1-2 ng/m3; IV >2 ng/m3; § Observed cases; §§ Rate Ratios vs reference category, adjusted by age and socioeconomic status. Period: 1990-2003.

Table 5 reports the results for cancer mortality and cancer incidence for men and women. For men, no clear relation with increasing exposure to heavy metal was suggested for site-specific cancer mortality and incidence, with the only exception of colon-rectal cancer mortality that was doubled in the third and fourth exposure categories. On the contrary, a clear trend of increasing overall cancer mortality was seen among women. The all-cancer mortality results appeared mainly due to a gradient of increasing risk for stomach, colon, liver, breast, bladder and lympho-haemopoietic cancer (mainly non-Hodgkin's lymphoma and myeloma). Notably, the rate ratio for breast cancer in the highest exposure category was 2.00 $(95 \% \mathrm{CI}=1.0-3.99)$. Cancer incidence data did not confirm the results found for mortality as no clear trend was detected.

No cases were observed in the reference category for soft tissue sarcoma, therefore rate ratios could not be calculated. On the other hand, four incident cases were found in the third category of heavy metals among women $(R R=4.71$, not statistically significant, n.s. $)$. When results for men and women were combined, six deceased cases were found and an excess in the highest category of exposure $(\mathrm{RR}=16.54 ; 95 \% \mathrm{CI}=1.72-159.07)$ was detected.

When all analyses were repeated considering exposure to $\mathrm{NO}_{2}$ as a potential confounder, none of the rate ratios estimates changed substantially and the overall findings were confirmed (data not shown).

We performed an additional analysis of mortality considering only residents who were present in the study area in 1990 . This sub-cohort represents the $78.8 \%$ of the total cohort (91.3\% of the total person-years). The results were substantially similar with wider confidence intervals although statistical significance was reached for liver cancer among women at the 4th level of exposure $(\mathrm{RR}=7.39 ; 95 \% \mathrm{CI}=1.11-49.10$, based on 10 cases $)$.

\section{Discussion}

We evaluated mortality, cancer incidence and hospitalization for cardiovascular and respiratory diseases among people living close to incinerators using dispersion modelling to assess exposure. The internal analyses showed no association with non-cancer related mortality and 
Table 4 Associations between heavy metals concentration and hospitalization for specific causes in the cohort of residents in the area of Coriano (Italy) by cause (ICD-9) and gender

\begin{tabular}{|c|c|c|c|c|c|c|c|c|c|}
\hline \multirow{3}{*}{$\begin{array}{l}\text { Cause (ICD-9) } \\
\text { Acute Myocardic Infarction (AMl; 410) }\end{array}$} & \multirow{3}{*}{$\begin{array}{c}\text { Heavy metals }^{\dagger} \\
\text { I }\end{array}$} & \multicolumn{4}{|c|}{ Men } & \multicolumn{4}{|c|}{ Women } \\
\hline & & \multirow{2}{*}{$\frac{\text { obs }^{\S}}{40}$} & \multirow{2}{*}{$\frac{\mathbf{R R}^{\S \S}}{1.00}$} & \multicolumn{2}{|c|}{$95 \% \mathrm{Cl}$} & \multirow{2}{*}{$\frac{\text { obs }^{5}}{13}$} & \multirow{2}{*}{$\frac{\mathbf{R R}^{\S \S}}{1.00}$} & \multicolumn{2}{|c|}{$95 \% \mathrm{Cl}$} \\
\hline & & & & - & - & & & - & - \\
\hline & II & 29 & 0.76 & 0.44 & 1.30 & 15 & 1.08 & 0.48 & 2.41 \\
\hline & III & 33 & 0.84 & 0.53 & 1.33 & 12 & 0.96 & 0.44 & 2.10 \\
\hline & IV & 36 & 0.81 & 0.51 & 1.28 & 16 & 1.40 & 0.66 & 2.98 \\
\hline \multirow[t]{4}{*}{ Chronic heart failure (CHF; 428.0, 428.2, 428.9) $)^{\ddagger}$} & I & 30 & 1.00 & - & - & 27 & 1.00 & - & - \\
\hline & II & 55 & $2.03^{*}$ & 1.25 & 3.29 & 24 & 1.04 & 0.58 & 1.87 \\
\hline & III & 32 & 1.07 & 0.65 & 1.76 & 28 & 1.05 & 0.62 & 1.78 \\
\hline & IV & 26 & 0.78 & 0.46 & 1.33 & 38 & 1.48 & 0.90 & 2.46 \\
\hline \multirow[t]{4}{*}{ Chronic obstructive pulmonary disease (COPD; 490-496; esc. 493$)^{\ddagger}$} & 1 & 28 & 1.00 & - & - & 31 & 1.00 & - & - \\
\hline & II & 39 & 1.46 & 0.85 & 2.50 & 24 & 0.69 & 0.38 & 1.27 \\
\hline & III & 39 & 1.41 & 0.87 & 2.29 & 26 & 0.87 & 0.51 & 1.46 \\
\hline & IV & 45 & 1.43 & 0.89 & 2.31 & 18 & 0.63 & 0.35 & 1.14 \\
\hline \multirow[t]{4}{*}{ Acute Respiratory Diseases (460-466; 480-487) } & I & 67 & 1.00 & - & - & 70 & 1.00 & - & - \\
\hline & II & 73 & 0.98 & 0.67 & 1.42 & 65 & 0.83 & 0.56 & 1.22 \\
\hline & III & 80 & 1.18 & 0.86 & 1.64 & 63 & 0.91 & 0.65 & 1.28 \\
\hline & IV & 63 & 0.89 & 0.63 & 1.27 & 90 & 1.29 & 0.94 & 1.78 \\
\hline \multirow[t]{4}{*}{ Asthma $(493)^{\ddagger}$} & I & 6 & 1.00 & - & - & 10 & 1.00 & - & - \\
\hline & II & 5 & 1.15 & 0.33 & 4.09 & 3 & 0.50 & 0.14 & 1.86 \\
\hline & III & 1 & 0.19 & 0.02 & 1.58 & 5 & 0.59 & 0.20 & 1.74 \\
\hline & IV & 6 & 1.16 & 0.36 & 3.71 & 9 & 1.01 & 0.40 & 2.55 \\
\hline
\end{tabular}

${ }^{*} \mathrm{p}$-value < 0.05; +Categories of heavy metals: I (reference) $<0.5 \mathrm{ng} / \mathrm{m} 3$; II 0.5-1 ng/m3; III 1-2 ng/m3; IV >2 ng/m3; §Observed cases; §§ Rate Ratios vs reference category, adjusted by age and socioeconomic status; ¥Analyses for AMI, CHF and COPD was restricted to $35-74$ year olds; analysis for asthma was restricted to 0-64 year olds. Period: 1999-2003.

morbidity. However, predicted heavy metals concentrations, as indicator of air pollution from the incinerators, were somehow related to cancer mortality in women, in particular for stomach, colon, liver and breast cancer. In addition, a combined analysis of men and women suggested an increase in soft-tissue sarcoma mortality related to exposure to incinerators. The results were adjusted for socioeconomic status whereas there was no important confounding effect from pollution due to other sources.

The excesses detected in the areas with higher exposure levels were observed mainly among females. Of course, a chance finding could be an explanation given multiple testing but it should also considered that women are a more stable population than men and misclassification of exposure is less likely to have occurred. On the other hand, most of the associations that were found for mortality cancer outcomes were not confirmed by incidence data although the time window of follow-up was the same (1990-2003). A possible explanation of these findings is that the effect of the exposure on cancer incidence precedes the time window of our study so that only mortality is affected.

From the results of the present study it is difficult to determine the causality of the associations and which specific agent emitted from the plants could have an etiological role in the excess risk that we have found. Of course, we considered heavy metals as a surrogate marker for exposure to a complex mixture of pollutants. As for the results of other studies on incinerators, the role of exposure to dioxins could be of importance in this context. Dioxin refers to 210 congeners/isomers of structurally and chemically related polychlorinated dibenzo-para-dioxins (PCDDs) and polychlorinated dibenzofurans (PCDFs), and the 2,3,7,8-tetra-CDD (TCDD) is considered the most toxic dioxin congener in this group. Dioxins are persistent in the environment and resistant to biodegradation and are considered human carcinogens [21]. The MSW incinerator in Forlì did emit dioxins and the values were considered relatively high until 1996 [16]. Like in our female population, increases for all cancers and in particular for 
Table 5 Associations between heavy metals concentration and mortality/incidence of cancer in the cohort of residents in the area of Coriano (Italy) by cause (ICD-9) and gender

\begin{tabular}{|c|c|c|c|c|c|c|c|c|c|c|c|c|c|c|c|c|c|}
\hline \multirow{4}{*}{$\begin{array}{l}\text { Cause (ICD-9) } \\
\\
\text { All cancer } \\
(140-239)\end{array}$} & \multirow{4}{*}{$\begin{array}{c}\text { Heavy } \\
\text { metals }^{\dagger}\end{array}$} & \multicolumn{8}{|c|}{ Men } & \multicolumn{8}{|c|}{ Women } \\
\hline & & \multicolumn{4}{|c|}{ mortality } & \multicolumn{4}{|c|}{ cancer incidence } & \multicolumn{4}{|c|}{ mortality } & \multicolumn{4}{|c|}{ cancer incidence } \\
\hline & & \multirow{2}{*}{$\frac{\text { obs }^{\S}}{216}$} & \multirow{2}{*}{$\frac{\mathbf{R R}^{\S \S}}{1.00}$} & \multicolumn{2}{|c|}{ IC $95 \%$} & \multirow{2}{*}{$\frac{\text { obs }}{413}$} & \multirow{2}{*}{$\frac{\mathbf{R R}^{\dagger}}{1.00}$} & \multicolumn{2}{|c|}{ IC $95 \%$} & \multirow{2}{*}{$\frac{\text { obs s }^{\S}}{152}$} & \multirow{2}{*}{$\frac{\mathbf{R R}^{\S \S}}{1.00}$} & \multicolumn{2}{|r|}{ IC $95 \%$} & \multirow{2}{*}{$\frac{\text { obs }}{396}$} & \multirow{2}{*}{$\begin{array}{l}\mathbf{R R}^{\S} \\
1.00\end{array}$} & \multicolumn{2}{|c|}{ IC $95 \%$} \\
\hline & & & & - & - & & & - & - & & & - & - & & & - & - \\
\hline & II & 194 & 1.12 & 0.92 & 1.38 & 327 & 0.94 & 0.81 & 1.08 & 154 & 1.24 & 0.98 & 1.57 & 323 & 0.96 & 0.83 & 1.11 \\
\hline & III & 194 & 1.04 & 0.85 & 1.27 & 342 & 0.93 & 0.81 & 1.07 & 153 & 1.24 & 0.98 & 1.57 & 315 & 0.95 & 0.82 & 1.10 \\
\hline & IV & 65 & 0.85 & 0.64 & 1.12 & 136 & 0.87 & 0.72 & 1.06 & 65 & $1.47^{*}$ & 1.09 & 1.99 & 112 & 0.90 & 0.73 & 1.11 \\
\hline \multirow[t]{4}{*}{ Stomach (151) } & 1 & 20 & 1.00 & - & - & 27 & 1.00 & - & - & 13 & 1.00 & - & - & 24 & 1.00 & - & - \\
\hline & II & 20 & 1.44 & 0.76 & 2.73 & 28 & 1.18 & 0.69 & 2.00 & 13 & 1.32 & 0.59 & 2.98 & 22 & 1.02 & 0.57 & 1.81 \\
\hline & III & 22 & 1.12 & 0.60 & 2.08 & 36 & 1.47 & 0.89 & 2.42 & 28 & $2.51^{*}$ & 1.27 & 4.97 & 31 & 1.54 & 0.91 & 2.63 \\
\hline & IV & 7 & 0.85 & 0.35 & 2.03 & 13 & 1.24 & 0.64 & 2.40 & 7 & 1.86 & 0.73 & 4.75 & 8 & 1.09 & 0.49 & 2.44 \\
\hline Colon rectum & 1 & 18 & 1.00 & - & - & 45 & 1.00 & - & - & 13 & 1.00 & - & - & 34 & 1.00 & - & - \\
\hline & II & 11 & 0.61 & 0.28 & 1.35 & 31 & 0.82 & 0.52 & 1.29 & 16 & 1.32 & 0.61 & 2.87 & 27 & 0.91 & 0.55 & 1.51 \\
\hline & III & 25 & $2.10^{*}$ & 1.10 & 4.00 & 51 & 1.28 & 0.86 & 1.91 & 19 & 1.94 & 0.93 & 4.06 & 56 & $2.00^{*}$ & 1.31 & 3.06 \\
\hline & IV & 10 & 2.05 & 0.92 & 4.58 & 17 & 1.00 & 0.57 & 1.75 & 8 & 2.15 & 0.86 & 5.37 & 14 & 1.33 & 0.71 & 2.48 \\
\hline Liver (155) & 1 & 11 & 1.00 & - & - & 10 & 1.00 & - & - & 3 & 1.00 & - & - & 7 & 1.00 & - & - \\
\hline & II & 6 & 0.61 & 0.21 & 1.75 & 7 & 0.80 & 0.30 & 2.10 & 3 & 0.92 & 0.17 & 5.11 & 2 & 0.30 & 0.06 & 1.46 \\
\hline & III & 6 & 0.61 & 0.21 & 1.75 & 6 & 0.66 & 0.24 & 1.82 & 2 & 1.00 & 0.15 & 6.61 & 2 & 0.34 & 0.07 & 1.63 \\
\hline & IV & 1 & 0.27 & 0.03 & 2.18 & 1 & 0.26 & 0.03 & 2.01 & 3 & 5.10 & 0.94 & 27.80 & 2 & 0.94 & 0.20 & 4.53 \\
\hline Larinx (161) & 1 & 6 & 1.00 & - & - & 18 & 1.00 & - & - & 0 & 1.00 & - & - & 2 & 1.00 & - & - \\
\hline & II & 2 & 0.42 & 0.08 & 2.22 & 6 & 0.41 & 0.16 & 1.04 & 1 & - & - & - & 1 & 0.61 & 0.06 & 6.80 \\
\hline & III & 3 & 0.53 & 0.13 & 2.25 & 4 & 0.26 & 0.09 & 0.76 & 1 & - & - & - & 1 & 0.60 & 0.05 & 6.62 \\
\hline & IV & 0 & 0.00 & 0.00 & . & 1 & 0.15 & 0.02 & 1.14 & 0 & - & - & - & 1 & 1.60 & 0.15 & 17.64 \\
\hline Lung (162) & I & 54 & 1.00 & - & - & 69 & 1.00 & - & - & 15 & 1.00 & - & - & 16 & 1.00 & - & - \\
\hline & II & 50 & 1.17 & 0.78 & 1.76 & 60 & 1.04 & 0.73 & 1.47 & 12 & 0.95 & 0.43 & 2.11 & 19 & 1.36 & 0.70 & 2.65 \\
\hline & III & 56 & 1.15 & 0.78 & 1.71 & 64 & 1.05 & 0.75 & 1.48 & 10 & 0.89 & 0.39 & 2.06 & 11 & 0.82 & 0.38 & 1.78 \\
\hline & IV & 18 & 0.91 & 0.53 & 1.57 & 25 & 0.96 & 0.61 & 1.52 & 4 & 0.96 & 0.31 & 2.97 & 4 & 0.81 & 0.27 & 2.42 \\
\hline Soft tissue & 1 & 0 & 1.00 & - & - & 3 & 1.00 & - & - & 0 & 1.00 & - & - & 1 & 1.00 & - & - \\
\hline & II & 1 & - & - & - & 1 & 0.37 & 0.04 & 3.59 & 0 & - & - & - & 0 & 0.00 & - & - \\
\hline & III & 0 & - & - & - & 2 & 0.72 & 0.12 & 4.31 & 2 & - & - & - & 4 & 4.71 & 0.53 & 42.16 \\
\hline & IV & 1 & - & - & - & 1 & 0.84 & 0.09 & 8.06 & 2 & - & - & - & 0 & 0.00 & - & - \\
\hline Breast (175) & 1 & 0 & 1.00 & - & - & 0 & 1.00 & - & - & 21 & 1.00 & - & - & 125 & 1.00 & - & - \\
\hline & II & 0 & - & - & - & 0 & - & - & - & 22 & 1.33 & 0.73 & 2.43 & 90 & 0.89 & 0.68 & 1.17 \\
\hline & III & 0 & - & - & - & 0 & - & - & - & 18 & 1.02 & 0.55 & 1.92 & 81 & 0.78 & 0.59 & 1.03 \\
\hline & IV & 0 & - & - & - & 0 & - & & - & 13 & 2.00 & 1.00 & 3.99 & 30 & 0.76 & 0.51 & 1.13 \\
\hline Prostate (185) & 1 & 14 & 1.00 & - & - & 60 & 1.00 & - & - & 0 & 1.00 & - & - & 0 & 1.00 & - & - \\
\hline & II & 12 & 1.08 & 0.50 & 2.33 & 48 & 0.93 & 0.64 & 1.37 & 0 & - & - & - & 0 & - & - & - \\
\hline & III & 23 & 1.85 & 0.95 & 3.59 & 58 & 1.08 & 0.75 & 1.55 & 0 & - & - & - & 0 & - & - & - \\
\hline & IV & 8 & 1.57 & 0.66 & 3.74 & 29 & 1.27 & 0.82 & 1.99 & 0 & - & - & - & 0 & - & - & \\
\hline
\end{tabular}


Table 5 Associations between heavy metals concentration and mortality/incidence of cancer in the cohort of residents in the area of Coriano (Italy) by cause (ICD-9) and gender (Continued)

\begin{tabular}{|c|c|c|c|c|c|c|c|c|c|c|c|c|c|c|c|c|c|}
\hline \multirow[t]{4}{*}{ Bladder (188)§ } & I & 10 & 1.00 & - & - & 48 & 1.00 & - & - & 4 & 1.00 & - & - & 7 & 1.00 & - & \\
\hline & II & 13 & 1.50 & 0.62 & 3.61 & 33 & 0.83 & 0.53 & 1.29 & 4 & 1.09 & 0.25 & 4.78 & 9 & 1.49 & 0.55 & 4.01 \\
\hline & III & 14 & 1.50 & 0.64 & 3.51 & 32 & 0.76 & 0.48 & 1.18 & 3 & 1.00 & 0.21 & 4.82 & 5 & 0.85 & 0.27 & 2.68 \\
\hline & IV & 6 & 1.48 & 0.52 & 4.22 & 14 & 0.78 & 0.43 & 1.42 & 3 & 3.06 & 0.64 & 14.70 & 5 & 2.30 & 0.73 & 7.24 \\
\hline \multirow{4}{*}{$\begin{array}{l}\text { Central nerv. sys. } \\
(191-192 ; 225) \S\end{array}$} & I & 4 & 1.00 & - & - & 6 & 1.00 & - & - & 4 & 1.00 & - & - & 8 & 1.00 & - & \\
\hline & II & 3 & 0.51 & 0.10 & 2.55 & 9 & 1.84 & 0.65 & 5.17 & 4 & 0.76 & 0.17 & 3.43 & 5 & 0.77 & 0.25 & 2.36 \\
\hline & III & 5 & 1.65 & 0.38 & 7.21 & 7 & 1.32 & 0.44 & 3.93 & 6 & 2.38 & 0.61 & 9.21 & 6 & 0.90 & 0.31 & 2.61 \\
\hline & IV & 0 & 0.00 & - & - & 3 & 1.35 & 0.34 & 5.39 & 0 & 0.00 & - & - & 0 & 0.00 & - & \\
\hline \multirow{4}{*}{$\begin{array}{l}\text { Lymphoemat. } \\
\text { system (200-208) }\end{array}$} & 1 & 27 & 1.00 & - & - & 50 & 1.00 & - & - & 17 & 1.00 & - & - & 34 & 1.00 & - & \\
\hline & II & 19 & 0.87 & 0.47 & 1.62 & 31 & 0.75 & 0.48 & 1.18 & 14 & 0.93 & 0.44 & 1.97 & 29 & 1.02 & 0.62 & 1.67 \\
\hline & III & 14 & 0.58 & 0.30 & 1.14 & 34 & 0.77 & 0.50 & 1.19 & 12 & 0.94 & 0.44 & 2.05 & 23 & 0.81 & 0.48 & 1.38 \\
\hline & IV & 4 & 0.42 & 0.15 & 1.23 & 13 & 0.70 & 0.38 & 1.28 & 8 & 1.78 & 0.74 & 4.25 & 13 & 1.23 & 0.65 & 2.33 \\
\hline \multirow{4}{*}{$\begin{array}{l}\text { Non-Hodgkin } \\
\text { Limphoma } \\
(200,202)\end{array}$} & 1 & 10 & 1.00 & - & - & 23 & 1.00 & - & - & 7 & 1.00 & - & - & 15 & 1.00 & - & \\
\hline & II & 6 & 0.80 & 0.28 & 2.29 & 10 & 0.54 & 0.26 & 1.14 & 7 & 0.83 & 0.27 & 2.56 & 14 & 1.10 & 0.53 & 2.29 \\
\hline & III & 6 & 0.63 & 0.22 & 1.82 & 13 & 0.65 & 0.33 & 1.28 & 2 & 0.47 & 0.09 & 2.44 & 8 & 0.64 & 0.27 & 1.51 \\
\hline & IV & 2 & 0.52 & 0.11 & 2.45 & 5 & 0.59 & 0.23 & 1.57 & 3 & 2.03 & 0.48 & 8.67 & 5 & 1.06 & 0.39 & 2.93 \\
\hline \multirow[t]{4}{*}{ Myeloma (203) } & I & 7 & 1.00 & - & - & 13 & 1.00 & - & - & 3 & 1.00 & - & - & 8 & 1.00 & - & \\
\hline & II & 3 & 0.37 & 0.09 & 1.62 & 14 & 0.45 & 0.16 & 1.27 & 1 & 0.32 & 0.03 & 3.53 & 9 & 0.36 & 0.10 & 1.30 \\
\hline & III & 2 & 0.33 & 0.06 & 1.72 & 11 & 0.61 & 0.24 & 1.52 & 3 & 1.44 & 0.26 & 7.93 & 9 & 0.48 & 0.15 & 1.54 \\
\hline & IV & 0 & 0.00 & - & - & 5 & 0.61 & 0.17 & 2.13 & 3 & 4.28 & 0.77 & 23.80 & 3 & 0.95 & 0.26 & 3.45 \\
\hline \multirow{4}{*}{$\begin{array}{l}\text { Leukaemia } \\
(204-208)\end{array}$} & 1 & 9 & 1.00 & - & - & 13 & 1.00 & - & - & 5 & 1.00 & - & - & 10 & 1.00 & - & \\
\hline & II & 9 & 1.33 & 0.51 & 3.49 & 5 & 1.27 & 0.60 & 2.72 & 6 & 1.82 & 0.54 & 6.19 & 3 & 1.31 & 0.50 & 3.40 \\
\hline & III & 6 & 0.78 & 0.27 & 2.25 & 7 & 0.94 & 0.42 & 2.11 & 7 & 1.69 & 0.52 & 5.55 & 4 & 1.35 & 0.52 & 3.49 \\
\hline & IV & 2 & 0.67 & 0.14 & 3.16 & 3 & 1.01 & 0.36 & 2.84 & 2 & 1.31 & 0.25 & 6.95 & 3 & 1.23 & 0.33 & 4.62 \\
\hline
\end{tabular}

${ }^{*}$ p-value $<0.05 ;{ }^{\dagger}$ Categories of heavy metals: I (reference) $<0.5 \mathrm{ng} / \mathrm{m}^{3} ;$ II 0.5-1 ng/m $\mathrm{m}^{3}$; II 1-2 ng/m ${ }^{3}$; IV $>2 \mathrm{ng} / \mathrm{m}^{3}$; §Observed cases; §§Rate Ratios (RR) versus the reference category of heavy metals adjusted for age and socioeconomic status; $\neq$ ICD-9 codes considered for cancer incidence were: bladder cancer $=$ $188 ; 223.3 ; 223.7 ; 236.7 ; 239.4$; cancer of the central nervous system $=191-192$. Period: $1990-2003$.

cancer of the digestive system (stomach and colon rectum) have been observed among occupational cohorts exposed to dioxin [22] and in the Seveso population, among residents in the more contaminated areas [23]. In addition, among women we observed an increase in mortality for Hodgkin's disease and myeloma (based on few cases and not statistically significant) as it has been reported among Seveso women [24] and in a French study [11] where the increase of blood cancer was related to dioxin exposure from incinerators. We observed a clear excess for breast cancer but the literature on the risk of breast cancer in the proximity of incinerators is rather poor [1,2]. No breast cancer excesses were observed in Seveso's longitudinal study, following the 1976 accident [25]; however, the Seveso
Women's Health Study reported a two-fold risk for breast cancer among pre-menopausal women with highest serum levels of TCDD [26]. There are several other studies that have found increased breast cancer incidence [27-29] in females occupationally exposed to dioxins. Finally, as in our observation, several studies have related residency in proximity of incinerators with liver cancer [8] and soft tissue sarcoma [10,2,14,30,31] although negative results also exist [32].

The strength of this work is the longitudinal study design adopted, in which individuals were followed for various health outcomes, exposure was assessed with advanced modelling techniques, socioeconomic status and other environmental exposures were also considered as potential confounders. To our knowledge, there are 
no other studies on incinerators conducted at the individual level with the details that we took into account. Despite that, the methodological aspects of the study and the main limitations should be considered.

Exposure assessment is a critical component of the study. We define the study population as people living up to $3.5 \mathrm{~km}$ far from the plants. This choice is based on previous studies $[8,10]$ and information by model simulations on the profile of the distribution of pollutant emitted by plants. In fact, this choice provided a good contrast of exposure conditions and a better comparability of the contrasted population groups. We geo-coded all the residential addresses and exposure was assessed using the results of a model of dispersion of pollutants into the atmosphere. A French study has validated Gaussian dispersion model for dioxins from an incinerator with a campaign of measurements on the ground in 75 sampling points [33]. The results confirmed the validity of the model in defining the different gradients of exposure, and identified inconsistencies between measured levels and those estimated by the model only in the presence of complex topographical situations (e.g. hills), a condition that does not apply to the Po Valley. A recent British study compared the use of distance as a proxy of exposure from a source of pollution by means of estimates derived from dispersion models and concluded that the use of the models significantly reduces the risk of misclassification embedded in the use of the distance from a point source [34].

The approach we used for exposure assessment has several assumptions and limitations. First of all, we considered only exposure to air pollution whereas other exposure routes, such as soil contamination or food and water consumption, could have importance. We considered only the individual residences at the beginning of the follow-up and this choice was supported by the observation that the exposure category never changed during the study for over $90 \%$ of the subjects (Table 2 ). Also, exposure was assessed at the beginning of followup to account for diseases with a long period of induction-latency (such as cancer) where the relevant exposure does not necessarily correspond to when it was diagnosed but to exposure levels in the previous years or decades. We used authorized emission values of pollutants to simulate dispersion from incinerators. This could have overestimated concentration values, but the shape of the fallout and the gradients of exposure are not sensitive to this choice. Finally, we assumed that heavy metals are better tracer for incinerator pollution than other pollutants since there is vast literature that indicates different heavy metals (such as $\mathrm{Cd}, \mathrm{Ni}, \mathrm{As}$, $\mathrm{Pb}, \mathrm{Zn}, \mathrm{Cu}, \mathrm{Mn}$ ) as possible tracers of incinerators $[16,35,36]$, and this choice was supported by monitoring campaigns conducted during the study period.
The role of the potential confounders, in particular other occupational and/or environmental exposures, should be considered. We observed a cluster of incidence and mortality for pleural cancer among men in the second exposure category; the absolute number of cases is low, but the relative risk is high. This cluster is due to occupational exposure to asbestos in the small industrial area in the second exposure category. There are other environmental factors in the study area due to the proximity of the highway and the urban area. We took into account the effect of exposure to vehicular traffic using predicted $\mathrm{NO}_{2}$ levels; the dispersion model for $\mathrm{NO}_{2}$ showed no overlap between the areas of high $\mathrm{NO}_{2}$ and the areas of high heavy metal levels. The traffic-related pollutants in this case would act, at least in theory, as negative confounders. However, when $\mathrm{NO}_{2}$ levels where considered in the analysis no important changes in the relative risk estimates were noted, even for respiratory mortality.

An additional limit, like many other epidemiological investigations, is the lack of individual data about potential confounding factors such as individual socioeconomic conditions, occupational exposure, and personal lifestyle factors such as smoking habits. Data on socioeconomic status, available at the aggregate level (census tract), allowed us to indirectly take into account other factors related to mortality and/or cancer incidence (i.e. smoking habits and occupational exposure are strongly linked to socioeconomic conditions). In fact, rate ratios estimates were attenuated after adjusting for socioeconomic status (all causes, cardiovascular diseases and some cancer types; data before adjustment are not reported). On the basis of these findings, we cannot exclude the possibility of a residual confounding by socioeconomic status.

It is notable that the lack of information about residential history before 1990 has limited the possibility of evaluating the effects of duration of exposure and latency since first exposure, two common useful measures in cohort analysis. Finally, as already indicated, power limitations given the size of the population studied may have limited the possibility to provide stable results. In fact, the study was able to detect a relative risk of 1.3 in the last category of exposure for all cancer combined (with $\alpha=0.95$ and $\beta=0.80$ ).

\section{Conclusions}

We found some excesses of cancer mortality among residents in areas with the highest predicted concentration of heavy metals. These findings might be possibly related to pollutants released from the incinerators over the past decades. This study contributes to the controversy over the possible health effects of waste management. However, future research into the health risks of 
waste management needs an accurate characterization of individual exposure, an improved knowledge of chemical and toxicological data of specific compounds, multi-site studies of large populations to increase statistical power, approaches based on individuals rather than communities and a better control of confounding factors. In this view, an ongoing multi-site project over the entire Emilia-Romagna region is investigating possible health effects due to exposure to all eight incinerators operating in the region.

\section{List of Abbreviations}

ADMS: Atmospheric Dispersion Model System; ARPA: Regional Agency for Environmental Prevention; As: Arsenic; BTX: Benzene, Toluene, Xilene; C6H6: Benzene; Cd: Cadmium; CO: Carbon monoxide; Cu: Copper; GIS: Geographic Information System; HCl: Hydrochloric acid; HW: Hospital Waste; Mn: Manganese; MSW: Municipal Solid Waste; Ni: Nickel; NO2: nitrogen dioxide; PAH: Polycyclic aromatic hydrocarbon; Pb: Lead; PCB: Polychlorinated biphenyls; PCDD: Polychlorinated dibenzodioxins; PCDF: Polychlorinated dibenzofurans; RR: Rate Ratio; SD: Standard Deviation; SES: Socioeconomic Status; SIR: Standardized Incidence Ratio; SMR: Standardized Mortality Ratio; SOx: Sulfur Oxides; TCDD: 2,3,7,8-Tetrachlorodibenzo-p-dioxins; TSP: Total Suspended Particles; VOC: Volatile Organic Compounds; Zn: Zinc.

\section{Acknowledgements}

The authors wish to thank Giulia Cesaroni and Chiara Badaloni, Department of Epidemiology ASL/RME, for their contribution in the computation of the socioeconomic index for the study area, Cristina Regazzi of Regional Agency for Environmental Prevention of Emilia Romagna, (Italy) for its support in environmental data collection, the Public Health Department of the Local Health Authority of Forli and the Romagna Cancer Registry for their contribution to the study, and Margaret Becker for her help in reviewing the English version of the manuscript. We thank Benedetto Terracini for his comments to an earlier draft.

The study was funded from the Interreg IIIC European Project "Enhance health: Environmental health surveillance system in urban areas near incinerators and industrial premises", financed by the European Regional Development Fund (ERDF)

\section{Author details}

'Environmental Health Reference Centre, Regional Agency for Environmental Prevention of Emilia Romagna, Modena, Italy. ${ }^{2}$ Department of Epidemiology - Lazio Regional Health Service, Rome, Italy.

\section{Authors' contributions}

AR and VF participated in the design of the study, performed the statistical analysis and drafted the manuscript. LE participated in the acquisition of environmental data and exposure assessment. PL participated in study conceiving and design. CAP has been involved in coordination and interpretation. FF coordinated the design of the study, the statistical analyses and helped to draft the manuscript. All authors read and approved the final manuscript.

\section{Competing interests}

The authors declare that they have no competing interests.

Received: 28 July 2010 Accepted: 24 March 2011

Published: 24 March 2011

\section{References}

1. Franchini M, Rial M, Buiatti E, Bianchi F: Health effects of exposure to waste incinerator emissions: a review of epidemiological studies. Ann Ist Super Sanita 2004, 40:101-15.

2. WHO: Population health and waste management: scientific data and policy options. Report of a WHO workshop, Rome, Italy; 2007 [http://www. euro.who.int/_data/assets/pdf_file/0012/91101/E91021.pdf].
3. Porta D, Milani S, Lazzarino Al, Perucci CA, Forastiere F: Systematic review of epidemiological studies on health effects associated with management of solid waste. Environmental Health 2009, 8:60.

4. Tango T, Fujita T, Tanihata T, Minowa M, Doi Y, Kato N, Kunikane S, Uchiyama I, Tanaka M, Uehata T: Risk of adverse reproductive outcomes associated with proximity to municipal solid waste incinerators with high dioxin emission levels in Japan. J Epidemiol 2004, 14:83-93.

5. Vinceti M, Malagoli C, Teggi S, Fabbi S, Goldoni C, De Girolamo G, Ferrari P, Astolfi G, Rivieri F, Bergomi M: Adverse pregnancy outcomes in a population exposed to the emissions of a municipal waste incinerator. Sci Total Environ 2008, 407:116-21.

6. Dummer TJ, Dickinson HO, Parker L: Adverse pregnancy outcomes around incinerators and crematoriums in Cumbria, north west England, 1956-93. J Epidemiol Community Health 2003, 57:456-61.

7. $L i n C H, L i C Y$, Mao I-F: Birth outcomes of infants born in areas with elevated ambient exposure to incinerators generated PCDD/F. Environ Int 2006, 32:624-629.

8. Elliott P, Hills M, Beresford J, Kleinschmidt I, Jolley D, Pattenden $S$, Rodrigues L, Westlake A, Rose G: Incidence of cancers of the larynx and lung near incinerators of waste solvents and oils in Great Britain. Lancet 1992, 339:854-8.

9. Elliott P, Shaddick G, Kleinschmidt I, Jolley D, Walls P, Beresford J, Grundy C: Cancer incidence near municipal solid waste incinerators in Great Britain. Br J Cancer 1996, 73:702-10.

10. Viel JF, Arveux P, Baverel J, Cahn JY: Soft-tissue sarcoma and nonHodgkin's lymphoma clusters around a municipal solid waste incinerator with high dioxin emission levels. Am J Epidemiol 2000, 152:13-9.

11. Floret N, Mauny F, Challier B, Arveux P, Cahn JY, Viel JF: Dioxin emissions from a solid waste incinerator and risk of non-Hodgkin lymphoma. Epidemiology 2003, 14:392-8.

12. Viel JF, Daniau C, Goria S, Fabre P, de Crouy-Chanel P, Sauleau EA, Empereur-Bissonnet P: Risk for non Hodgkin's lymphoma in the vicinity of French municipal solid waste incinerators. Environ Health 2008, 7:51.

13. Comba P, Ascoli V, Belli S, Benedetti M, Gatti L, Ricci P, Tieghi A: Risk of soft tissue sarcomas and residence in the neighbourhood of an incinerator of industrial wastes. Occup Environ Med 2003, 60:680-3.

14. Zambon P, Ricci P, Bovo E, Casula A, Gattolin M, Fiore AR, Chiosi F, Guzzinati S: Sarcoma risk and dioxin emissions from incinerators and industrial plants: a population-based case-control study (Italy). Environ Health 2007, 16:6-19.

15. Cordier S, Lehébel A, Amar E, Anzivino-Viricel L, Hours M, Monfort C, Chevrier C, Chiron M, Robert-Gnansia E: Maternal residence near municipal waste incinerators and the risk of urinary tract birth defects. Occup Environ Med 2010, 67:493-499.

16. Morselli L, Passarini F, Bartoli M: The environmental fate of heavy metals arising from a MSW incineration plant. Waste Manag 2002, 22:875-81.

17. ARPA Emilia Romagna: "Environmental study in the industrial urban area of Coriano". (Italian report) 2001, Ott.

18. Cambridge Environmental Research Consultants, Cambridge, UK

19. ESRI : ArcView GIS: Relase 8.2 Redlands, California, USA; 2002.

20. StataCorp: Stata Statistical Software: Release 10. College Station, TX: StataCorp LP; 2007.

21. International Agency for Research on Cancer: Polychlorinated dibenzopara-dioxins and polychlorinated dibenzofurans. IARC Monographs on the Evaluation of Carcinogenic Risks to Humans 1997, 69:33-343.

22. 't Mannetje A, McLean D, Cheng S, Boffetta P, Colin D, Pearce N: Mortality in New Zealand workers exposed to phenoxy herbicides and dioxins. Occup Environ Med 2005, 62:34-40.

23. Steenland K, Bertazzi P, Baccarelli A, Kogevinas M: Dioxin revisited: developments since the 1997 IARC classification of dioxin as a human carcinogen. Environ Health Perspect 2004, 112:1265-8.

24. Bertazzi A, Pesatori AC, Consonni D, Tironi A, Landi MT, Zocchetti C: Cancer incidence in a population accidentally exposed to $2,3,7,8-$ tetrachlorodibenzo-para-dioxin. Epidemiology 1993, 4:398-406.

25. Consonni D, Pesatori AC, Zocchetti C, Sindaco R, D'Oro LC, Rubagotti M, Bertazzi PA: Mortality in a population exposed to dioxin after the Seveso, Italy, accident in 1976: 25 years of follow. Am J Epidemiol 2008, 167:847-858.

26. Warner M, Eskenazi B, Mocarelli P, Gerthoux PM, Samuels S, Needham L, Patterson D, Brambilla P: Serum dioxin concentrations and breast cancer 
risk in the Seveso Women's Health Study. Environ Health Perspect 2002, 110:625-8.

27. Flesch-Janys D, Becher H, Manz A, Morgenstern I, Nagel S, Steindorf K: Epidemiologic investigation of breast cancer incidence in a cohort of female workers with high exposure to $\mathrm{PCDD} / \mathrm{F}$ and $\mathrm{HCH}$. Organohalogen Compounds 1999, 44:379-382.

28. Manz A, Berger J, Dwyer J, Flesch-Janys D, Nagel S, Waltsgott H: Cancer mortality among workers in chemical plant contaminated with dioxin. Lancet 1991, 338:959-964

29. Kogevinas M, Becher H, Benn T, Bertazzi PA, Boffetta P, Bueno-deMesquita HB, Coggon D, Colin D, Flesch-Janys D, Fingerhut M, Green L, Kauppinen T, Littorin M, Lynge E, Mathews JD, Neuberger M, Pearce N, Saracci R: Cancer mortality in workers exposed to phenoxy herbicides, chlorophenols, and dioxins: An expanded and updated international cohort study. Am J Epidemiol 1997, 145:1061-1075.

30. Comba P, Fazzo L, Berrino F: Soft tissue sarcomas in Mantua: epidemiological evidence and perspectives for environmental remediation. Epidemiol Prev 2004, 28:266-71.

31. Tessari R, Canova C, Canal F, Lafisca S, Inio A, Murer B, Stracca V, Tollot M, Simonato L: Environmental pollution from dioxins and soft tissue sarcomas in the population of Venice and Mestre: an example of the use of current electronic information sources. Epidemiol Prev 2006, 30:191-8.

32. Tuomisto JT, Pekkanen J, Kiviranta $H$, Tukiainen E, Vartiainen T, Tuomisto J: Soft-tissue sarcoma and dioxin: A case-control study. Int J Cancer 2004, 108:893-900.

33. Floret N, Viel JF, Lucot E, Dudermel PM, Cahn JY, Badot PM, Mauny F: Dispersion modeling as a dioxin exposure indicator in the vicinity of a municipal solid waste incinerator: a validation study. Environ Sci Technol 2006, 40:2149-55.

34. Hodgson S, Nieuwenhuijsen MJ, Colvile R, Jarup L: Assessment of exposure to mercury from industrial emissions: comparing "distance as a proxy" and dispersion modelling approaches. Occup Environ Med 2007, 64:380-8.

35. Yuan CS, Lin HY, Wu CH, Liu MH: Partition and size distribution of heavy metals in the flue gas from municipal solid waste incinerators in Taiwan. Chemosphere 2005, 59:135-145.

36. Hu CW, Chao MR, Wu KY, Chang-Chien GP, Lee WY, Chang LW, Lee WS: Characterization of multiple airborne particulate metals in the surroundings of a municipal waste incinerator in Taiwan. Atmos Environ 2003, 37:2845-2852.

doi:10.1186/1476-069X-10-22

Cite this article as: Ranzi et al: Mortality and morbidity among people living close to incinerators: a cohort study based on dispersion modeling for exposure assessment. Environmental Health 2011 10:22.

\section{Submit your next manuscript to BioMed Central and take full advantage of:}

- Convenient online submission

- Thorough peer review

- No space constraints or color figure charges

- Immediate publication on acceptance

- Inclusion in PubMed, CAS, Scopus and Google Scholar

- Research which is freely available for redistribution 